\title{
Impact of venous ulcers on patients' quality of life: an integrative review
}

\author{
Impacto das úlceras venosas na qualidade de vida dos pacientes: revisão integrativa \\ Impacto de las úlceras venosas en la calidad de vida de los pacientes: revisión integrativa
}

\section{Fabiana Lopes Joaquim', Rose Mary Costa Rosa Andrade Silva', Maria Paz Garcia-Caro", Francisco Cruz-Quintana'I", Eliane Ramos Pereira'}
'Universidade Federal Fluminense, Aurora de Afonso Costa School of Nursing. Niterói, Rio de Janeiro, Brazil. "Universidad de Granada, Facultad de Ciencias de la Salud. Andalucía, Granada, España.
"' Universidad de Granada, Facultad de Psicología. Andalucía, Granada, España.

\section{How to cite this article:}

Joaquim FL, Silva RMCRA, Garcia-Caro MP, Cruz-Quintana F, Pereira ER. Impact of venous ulcers on patients' quality of life: an integrative review. Rev Bras Enferm [Internet]. 2018;71(4):2021-9. DOI: http://dx.doi.org/10.1590/0034-7167-2017-0516

\section{Submission: 07-16-2017 Approval: 11-25-2017}

\begin{abstract}
Objective: To analyze knowledge gathered about the impact of venous ulcers on patients' quality of life. Method: Systematic bibliographic review study with an integrative approach. Databases of MEDLINE, LILACS, IBECS, CINAHL Complete, Web of Science, Scopus, and CUIDEN Plus were used for selection with the PICOT guiding criteria, through the DeCS and MeSH: adult, aged, varicose ulcer, and quality of life, in Portuguese, Spanish, and English. The inclusion criteria were: full original articles available in the databases selected with adherence to the theme in Portuguese, Spanish, and English, published from 2007 to 2016. Results: The sample included 14 national and international articles with different methodological approaches and investigative contexts, published from 2012 to 2016. Conclusion: Chronic venous ulcers act on patients' bio-psycho-socialspiritual and socioeconomic spheres, having a negative impact on their quality of life.
\end{abstract}

Descriptors: Varicose Ulcer; Quality of Life; Adult; Aged; Review.

\section{RESUMO}

Objetivo: analisar as produções de conhecimento sobre o impacto das úlceras venosas na qualidade de vida dos pacientes. Método: estudo de revisão bibliográfica sistemática, do tipo integrativa. Utilizaram-se, para seleção, as bases de dados MEDLINE; LILACS; IBECS; CINAHL Complete; Web of Science; Scopus e CUIDEN Plus, pelos critérios orientadores PICOT; através do DECs e MeSH: adulto, idoso, úlcera varicosa e qualidade de vida, nos idiomas português, espanhol e inglês. Os critérios de inclusão foram: artigos originais disponibilizados na íntegra, nas bases de dados selecionadas, com aderência à temática nos idiomas Português, Espanhol e Inglês, publicados entre os anos de 2007 e 2016. Resultados: a amostra incluiu 14 artigos nacionais e internacionais com diversas abordagens metodológicas e contextos investigativos, publicados entre os anos de 2012 e 2016. Conclusão: as úlceras venosas crônicas atuam sobre as esferas biopsicoespiritual e socioeconômica dos pacientes, repercutindo negativamente sobre a qualidade de vida.

Descritores: Úlcera Varicosa; Qualidade de Vida; Adulto; Idoso; Revisão.

\section{RESUMEN}

Objetivo: Analizar las producciones de conocimiento sobre el impacto de las úlceras venosas en la calidad de vida de los pacientes. Método: Estudio de revisión bibliográfica sistemática, tipo integrativa. Para la selección, se utilizaron las bases de datos MEDLINE; LILACS; IBECS; CINAHL Complete; Web of Science; Scopus y CUIDEN Plus, con criterios orientadores PICOT; mediante DECs y MeSH: adulto, anciano, úlcera varicosa y calidad de vida, en portugués, español e inglés. Fueron criterios de inclusión: artículos originales integralmente disponibles en las citadas bases, referentes a la temática, en idiomas Portugués, Español e Inglés, publicados entre los años 2007 y 2016. Resultados: La muestra incluyó 14 artículos nacionales e internacionales con diversos abordajes metodológicos y contextos de investigación, en publicaciones realizadas desde 2012 hasta 2016. Conclusión: Las úlceras venosas crónicas actúan sobre las esferas biopsicoespiritual y socioeconómica de los pacientes, con repercusiones negativas en la calidad de vida.

Descriptores: Úlcera Varicosa; Calidad de Vida; Adulto; Anciano; Revisión. 


\section{INTRODUCTION}

Increases in the life expectancy lead to a rise in the incidence of chronic diseases, which results in specific practices of healthcare professionals for the promotion of care, with the purpose of reducing the impact of these pathologies on the patients affected, as well as providing them with quality of life ${ }^{(1)}$.

In this context, non-communicable chronic diseases are included that, in terms of presenting high incidence and prevalence rates, may lead to patient disability and premature mortality. Because these issues are related to the illness process, they must be understood and interpreted by healthcare professionals, in order to achieve satisfactory results from the care provided. Chronic venous ulcers are found among the noncommunicable diseases that affect the population.

According to the Scottish Intercollegiate Guidelines Network ${ }^{(2)}$, venous ulcers are the most severe wounds found in chronic venous insufficiency syndrome of the lowers limbs, and are thus characterized as a public health issue ${ }^{(3)}$. Epidemiological data indicate that these wounds represent approximately $80 \%$ to $90 \%$ of leg ulcer cases ${ }^{(45)}$.

The clinical condition of venous ulcers in the population affected causes difficulties associated with activities of daily living, due to pain, depression, loss of self-esteem, social isolation, work incapacity, and hospitalizations or outpatient consultations ${ }^{(6)}$. Social reclusion and feelings of shame are also seen in the population affected, due to aesthetic changes and clinical/functional disorders caused by ulcerative wounds $^{(7)}$. In addition to this, living with the disease tends to lead to discrimination and, in most cases, to lack of support from family members and friends, thus affecting these patients' quality of life.

Therefore, promoting the quality of life of this population is of utmost importance. The recommendations of the World Health Organization defines quality of life as "individuals' perception that their needs are being met or that opportunities to achieve their happiness and self-fulfillment are being denied, regardless of their physical health condition or social and economic situation" ${ }^{\prime \prime(8)}$.

The present study is related to the overall healthcare area, which is responsible for intervening in issues and situations related to the population's health in general or to that of a specified group. It is relevant for presenting the issue of quality of life associated with chronic venous ulcers, because this pathology causes fear; anxiety; the expectation of a loss of well-being; limitation; impediment to the practice of activities of daily living; and social and professional restrictions. Thus it leads to high social and economic costs ${ }^{(9)}$.

\section{OBJECTIVE}

To analyze knowledge gathered about the impact of chronic venous ulcers on patients' quality of life.

\section{METHOD}

\section{Study design}

The methodology adopted for the development of the present study was a systematic bibliographic review with an integrative approach. This methodology allows for scientific knowledge to be systemized so that researchers are able to come close to the theme to be studied, outline an overview on scientific productions on the theme with its evolution over time, and envision the possibilities of research ${ }^{(10)}$.
This type of review is developed by following the next six steps: identification of the theme and selection of the research question; establishment of inclusion and exclusion criteria for sample selection; identification of preselected and selected studies; categorization; analysis and interpretation of the results; and presentation of the review ${ }^{(10)}$.

The integrative systematic review was initially developed with the identification of the research theme, which was the quality of life in patients with chronic venous ulcers. Next, the research question was defined, which was the impact of chronic venous ulcers in patients' quality of life. From this definition, the study's guiding question was established, based on the PICOT strategy, which presents prognosis or prediction as a question for its formulation, in which " $\mathrm{P}$ " indicates who or which people, "I" shows how the pathology influences the prognosis, " $\mathrm{C}$ " compares the influence of the prognosis in the $\mathrm{ab}$ sence of the pathology, "O" shows the influence of the pathological prognosis on what will be studied, and " $\mathrm{T}$ " indicates the influence of the prognosis over time ${ }^{(11)}$. Therefore, the guiding question of the present study based on the PICOT strategy was: "Which factors influence the quality of life of adult and aged patients with venous ulcers during their treatment?" This is shown in Figure 1:

\begin{tabular}{|c|l|}
\hline P & - Adults and aged patients \\
\hline I & $\bullet$ How factors are related to chronic venous ulcers \\
\hline C & - Without comparison with the absence of the wound \\
\hline O & $\bullet$ Influence on patients' quality of life \\
\hline T & $\bullet$ During the treatment \\
\hline
\end{tabular}

Figure 1 - Illustrative diagram of the guiding question's development process

\section{Data source}

The search was undertaken in the following databases: MEDLINE (Medical Literature Analysis and Retrieval System Online); LILACS (Latin American and Caribbean Literature on Health Sciences); IBECS (Spanish Bibliographical Index of Health Sciences); BDENF (Nursing Database); CINAHL Complete (Cumulative Index to Nursing and Allied Health Literature); Web of Science; Scopus; and CUIDEN Plus.

\section{Data collection and organization}

The search strategy adopted was the use of descriptors and the Boolean operators "OR" and "AND." Descriptors relevant to the theme were selected based on the PICOT strategy and identified through DeCS and MeSH, namely: adult; aged; varicose ulcer; and quality of life. Therefore, these descriptors in Portuguese, Spanish, and English were used for the articles' search.

The inclusion criteria adopted for the search were: full original articles available in the selected databases that presented adherence to the theme in Portuguese, Spanish, and English, published from 2007 to 2016, with the aim of identifying evidence on the theme published within the last 10 years. The search was undertaken during May 2017.

The exclusion criteria adopted were scientific productions that only presented abstracts, and publications related to the validation of questionnaires.

The search with descriptors associated with Boolean operators enabled the identification of preselected studies (Figure 2). 


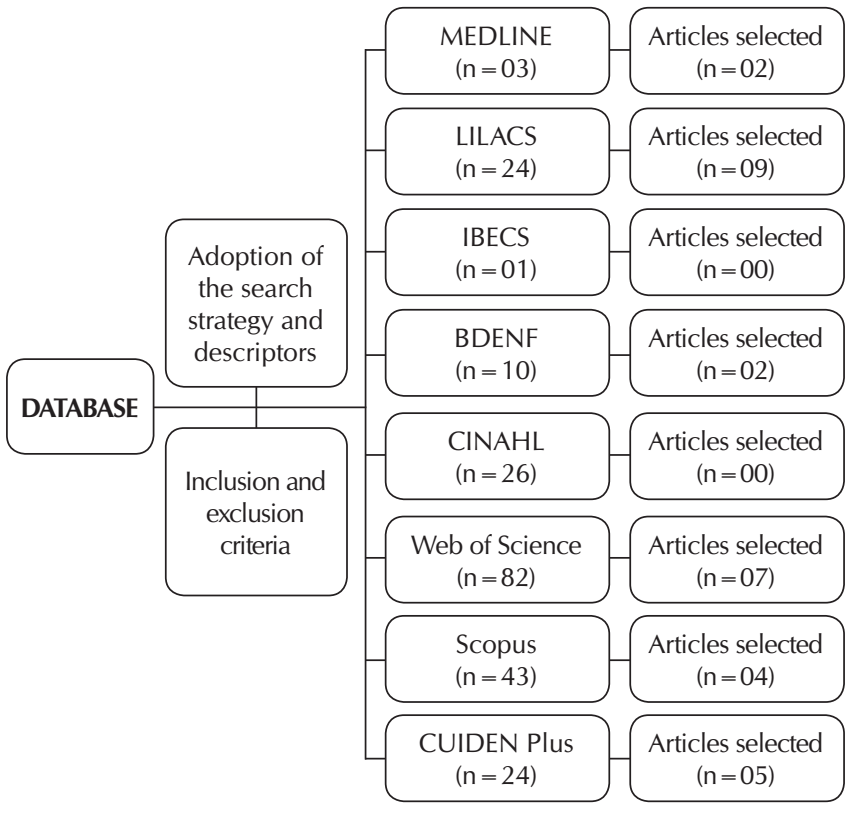

Figure 2 - Illustrative diagram of the methodological development for the identification of preselected studies and selection of the studies to be included in the review

After the identification of preselected studies $(n=213)$, the reading of the publications' titles, abstracts, and descriptors was carried out by two independent reviewers to verify their adequacy to the theme and relevance to be selected and included in the review (Figure 2), in order to proceed with the articles' full reading for categorization, analysis, and interpretation of the results, and presentation of the review.

The reading of the preselected material led to the exclusion of 184 publications because they: were related to the validation of questionnaires (LILACS: $\mathrm{n}=01 /$ Web of Science: $\mathrm{n}=02$ ); only presented the abstract (CINAHL: $n=03 /$ Web of Science: $n=$ 04/Scopus: $n=02$ ); or did not present adherence to the theme $(n=169)$. These articles were related to: therapy approaches in the healing process (LILACS: $\mathrm{n}=09$ /IBECS: $\mathrm{n}=01 / \mathrm{BDENF}$ : $n=07 / C I N A H L: n=23 /$ Web of Science: $n=69 /$ Scopus: $n=37 /$ CUIDEN Plus: $n=19$ ); assessment of depression symptoms (LILACS: $\mathrm{n}=04$ ); preliminary note (LILACS: $\mathrm{n}=01$ ); and integrative review (MEDLINE: $\mathrm{n}=01 / \mathrm{BDENF}$ : 01).

Twenty-nine articles published from 2012 to 2016 were selected. Of these, six were available 15 times in two or more databases. Therefore, these publications were excluded from the review. Consequently, at the end of the bibliographical survey, 14 articles were obtained for full reading to proceed with categorization, analysis, and interpretation of the results; and presentation of the review.

It is worth mentioning that the search was based on articles published from 2007 to 2016 . However, the reading of the selected material showed that articles published from 2007 to 2011 that met the inclusion criteria, did not effectively approach the theme quality of life, but rather issues related to procedures and care that improved quality of life, according to the authors, without describing and discussing dimensions that led to improvement.

\section{Data analysis}

Data analysis was carried out by means of a summarization of the methodological characteristics of the articles selected, with the goal of achieving the objective of the study. The data collected were described and organized in tables with information regarding PRISMA $^{(12)}$ guidelines and level of evidence ${ }^{(11)}$ (Chart 1); as well as references, objectives, method, participants, instrument, factors that influence quality of life, and dimensions affected (Chart 2).

\section{RESULTS}

The search in the databases initially resulted in 213 articles, of which 14 were included ${ }^{(13-26)}$ in the review. With the aim of verifying the quality of the scientific evidence, screening of the studies included in the integrative review (IR) was carried out according to PRISMA $^{(12)}$ guidelines and level of evidence ${ }^{(11)}$, as described in Chart 1.

Chart 1- Screening of the studies included in the IR, according to PRISMA ${ }^{(12)}$ guidelines and level of evidence ${ }^{(13)}$

\begin{tabular}{|c|c|c|c|c|c|c|c|}
\hline \multirow{2}{*}{ Reference } & \multirow{2}{*}{ Abstract } & \multirow{2}{*}{$\begin{array}{c}\text { Introduction } \\
\text { (Objectives) }\end{array}$} & \multirow{2}{*}{$\begin{array}{l}\text { Methods } \\
\text { (Protocols) }\end{array}$} & \multirow{2}{*}{ Discussion } & \multicolumn{2}{|c|}{ Funding } & \multirow{2}{*}{ Level of evidence $^{(11)}$} \\
\hline & & & & & Yes & No & \\
\hline Salomé GM, Ferreira LM. 2012 ${ }^{(13)}$ & $\mathrm{x}$ & $\mathrm{x}$ & $\mathrm{X}$ & $\mathrm{x}$ & & $\mathrm{x}$ & Nível VI \\
\hline Dias TYAF et al. $2013^{(14)}$ & $\mathrm{x}$ & $x$ & $x$ & $x$ & & $x$ & Nível VI \\
\hline Lopes CR et al. 2013 ${ }^{(15)}$ & $x$ & $x$ & $x$ & $\mathrm{x}$ & & $\mathrm{x}$ & Nível IV \\
\hline Dias TYAF et al. $2013^{(16)}$ & $\mathrm{x}$ & $\mathrm{X}$ & $x$ & $x$ & $\mathrm{X}$ & & Nível VI \\
\hline Saraiva DMRF et al. $2013^{(17)}$ & $\mathrm{x}$ & $x$ & $x$ & $x$ & & $\mathrm{x}$ & Nível VI \\
\hline Dias TYAF et al. 2014 & $x$ & $x$ & $x$ & $x$ & & $x$ & Nível VI \\
\hline Lozano SFS et al. 2014 ${ }^{(19)}$ & $x$ & $x$ & $X$ & $x$ & & $\mathrm{X}$ & Nível IV \\
\hline Torres GV et al. 2014 ${ }^{(20)}$ & $\mathrm{X}$ & $\mathrm{x}$ & $\mathrm{X}$ & $\mathrm{X}$ & & $\mathrm{X}$ & Nível VI \\
\hline Wachholz PA et al. 2014 & $x$ & $x$ & $x$ & $x$ & & $x$ & Nível VI \\
\hline Finlayson KJ et al. $2014^{(22)}$ & $\mathrm{x}$ & $\mathrm{X}$ & $\mathrm{x}$ & $\mathrm{X}$ & $\mathrm{x}$ & & Nível II \\
\hline Salomé GM et al. 2014(23) & $\mathrm{x}$ & $\mathrm{x}$ & $\mathrm{x}$ & $\mathrm{x}$ & & $\mathrm{x}$ & Nível III \\
\hline Sell BT et al. 2015 (24) & $x$ & $X$ & $X$ & $x$ & & $\mathrm{X}$ & Nível VI \\
\hline Tracz E et al. 2015(25) & $x$ & $x$ & $x$ & $x$ & & $x$ & Nível VII \\
\hline Araújo RO et al. $2016^{(26)}$ & $x$ & $x$ & $x$ & $x$ & & $x$ & Nível VI \\
\hline
\end{tabular}


The following classification was considered to evaluate the level of evidence ${ }^{(11)}$ : Level I, resulting from systematic reviews or metaanalysis; Level II, obtained by means of randomized controlled trials; Level III, derived from non-randomized control studies with a good design; Level IV, resulting from case-control studies or cohort studies; Level $\mathrm{V}$, obtained by means of systematic reviews of qualitative or descriptive studies; Level VI, resulting from qualitative or descriptive studies; and Level VII, with evidence deriving from the opinions of authorities or reports of committees of experts.

After checking the quality of the scientific evidence, regarding the year of publication, it was found that one article was from $2012^{(13)}$, four from 2013 (14-17), six from 2014 ${ }^{(18-23)}$, two from 2015 $5^{(24-25)}$, and one from $2016^{(26)}$. With regard to language, seven publications were in Portuguese ${ }^{(13,15-17,20,24,26)}$, five were in English ${ }^{(19,21-23,25)}$, and two were available in three languages, which were: Portuguese, Spanish, and English ${ }^{(14,18)}$.

Regarding the databases, there was a prevalence of articles that discussed the quality of life in patients with chronic venous ulcers as indexed in multiple databases. This prevalence was related to LILACS $(n=09)^{(13-16,18,20-21,24,26)}$, Web of Science $(n=07)^{(16-18,21-23,26)}$, CUIDEN Plus $(n=05)^{(16-18,22,26)}$, Scopus $(n=04)^{(16,18,25-26)}$, BDNF $(n=02)^{(16,18)}$, and MEDLINE $(\mathrm{n}=02)^{(18-19)}$.

The selected studies were developed in the following countries: Brazil $(n=8)^{(13,15-16,18,21,23-24,26)}$, Portugal $(n=01)^{(17)}$, Spain $(n=01)^{(19)}$, Australia $(n=01)^{(22)}$, and Poland $(n=01)^{(25)}$, with two articles having been developed in a partnership between Brazil and Portugal(14,20). Regarding summarization of the methodological characteristics of the selected articles, the data collected and shown in Charts 1 and 2 indicated that $100 \%(n=14)$ of the selected material presented a quantitative approach, with a prevalence of the evidence ${ }^{(11)}$ at Level VI $(n=09)^{(13-14,16-18,20-21,24,26)}$, followed by Level IV $(n=02)^{(15,19)}$, Level II $(n=01)^{(22)}$, Level III $(n=01)^{(23)}$, and Level VII $(n=01)^{(25)}$.

With regard to the most frequently adopted verbs in the description of the objectives, a prevalence of the verb "to compare" was found $(n=04)^{(14,18,20,22)}$, followed by the verbs "to evaluate" $(n=03)^{(13,17,23)}$, "to verify" $(n=02)^{(16,24)}$, "to analyze" $(n=02)^{(25-26)}$, "to correlate" $(n=01)$ (15), "to determine" $(\mathrm{n}=01)^{(19)}$, and "to identify" $\left(\mathrm{n}=1^{(21)}\right.$, these being in accordance with studies with a quantitative approach.

Chart 2 - Description of the studies included in the integrative review according to reference, objectives, method, participants, instrument, factors that influence quality of life, and dimensions affected

\begin{tabular}{|c|c|c|c|c|}
\hline Reference & Objectives & $\begin{array}{l}\text { Method/ Participants/ } \\
\text { Instrument }\end{array}$ & $\begin{array}{l}\text { Factors that influence on quality of } \\
\text { life }\end{array}$ & Dimensions affected \\
\hline $\begin{array}{l}\text { Salomé GM, } \\
\text { Ferreira LM. Rev } \\
\text { Bras Cir Plást. } \\
\text { 2012; 27(3): 466- } \\
71^{(13)} \text {. }\end{array}$ & $\begin{array}{l}\text { To evaluate the quality } \\
\text { of life of patients with } \\
\text { venous ulcers treated with } \\
\text { compression therapy with } \\
\text { Unna boot. }\end{array}$ & $\begin{array}{l}\text { Clinical, descriptive, } \\
\text { and analytical study/50 } \\
\text { participants/Short } \\
\text { Form-36 (SF-36). }\end{array}$ & $\begin{array}{l}\text { Impaired functional capacity; pain; } \\
\text { physical aspect; general health } \\
\text { condition. }\end{array}$ & $\begin{array}{l}\text { Social aspect; } \\
\text { emotional aspect; } \\
\text { vitality; mental health. }\end{array}$ \\
\hline $\begin{array}{l}\text { Dias TYAF et al. } \\
\text { Online Braz J } \\
\text { Nurs. 2013; } 12 \\
(2): 491-500^{(14)} \text {. }\end{array}$ & $\begin{array}{l}\text { To compare the quality of } \\
\text { life of patients with venous } \\
\text { ulcers in Natal, capital city } \\
\text { in the state of Rio Grande } \\
\text { do Norte, Brazil and Evora, } \\
\text { a city in Portugal. }\end{array}$ & $\begin{array}{l}\text { Analytical and } \\
\text { comparative study, } \\
\text { with a cross-sectional } \\
\text { design and quantitative } \\
\text { approach of treatment } \\
\text { and data analysis/170 } \\
\text { participants/SF-36. }\end{array}$ & $\begin{array}{l}\text { Difficulties in performing activities } \\
\text { of daily living due to functional } \\
\text { capacity impairment. }\end{array}$ & $\begin{array}{l}\text { Functional capacity; } \\
\text { pain; general health } \\
\text { condition; vitality; social } \\
\text { aspect; limitation due to } \\
\text { physical aspects; mental } \\
\text { health; emotional aspect. }\end{array}$ \\
\hline $\begin{array}{l}\text { Lopes CR et } \\
\text { al. J Vasc Bras. } \\
\text { 2013; 12(1): } \\
5-9^{(15)} \text {. }\end{array}$ & $\begin{array}{l}\text { To correlate changes } \\
\text { in the quality of life of } \\
\text { patients with venous } \\
\text { ulcers in lower limbs } \\
\text { with muscle activation } \\
\text { capacity. }\end{array}$ & $\begin{array}{l}\text { Prospective clinical } \\
\text { study, case-control in } \\
\text { which the subjects of } \\
\text { the study are their own } \\
\text { control/10 participants/ } \\
\text { SF-36. }\end{array}$ & $\begin{array}{l}\text { Significant reduction in the activation } \\
\text { of the soleus muscle in both legs due } \\
\text { to valvular incompetence, associated or } \\
\text { not with a obstructive condition; loss } \\
\text { of muscle strength; strength reduction } \\
\text { and increase in movements; pain; } \\
\text { frustration; work inactivity; lack of } \\
\text { willingness to go out. }\end{array}$ & $\begin{array}{l}\text { Emotional aspect; } \\
\text { limitation due to } \\
\text { physical aspects. }\end{array}$ \\
\hline $\begin{array}{l}\text { Dias TYAF et } \\
\text { al. Acta Paul } \\
\text { Enferm. 2013; } \\
\text { 26(6): 529- } \\
34^{(16)} \text {. }\end{array}$ & $\begin{array}{l}\text { To verify the influence } \\
\text { of care and clinical } \\
\text { characteristics on the } \\
\text { quality of life of patients } \\
\text { with venous ulcers (VU). }\end{array}$ & $\begin{array}{l}\text { Cross-sectional study } \\
\text { with convenience } \\
\text { sample/100 } \\
\text { participants/SF-36. }\end{array}$ & $\begin{array}{l}\text { Pain; reduced mobility; financial } \\
\text { instability; restrictions in personal } \\
\text { life. }\end{array}$ & $\begin{array}{l}\text { Limitation due to } \\
\text { physical aspects; } \\
\text { functional capacity; } \\
\text { vitality; pain; general } \\
\text { health condition. }\end{array}$ \\
\hline $\begin{array}{l}\text { Saraiva DMRF } \\
\text { et al. Referência. } \\
\text { 2013; 3(10): } \\
109-18^{(17)} \text {. }\end{array}$ & $\begin{array}{l}\text { To evaluate the quality } \\
\text { of life of patients with } \\
\text { chronic venous ulcers. }\end{array}$ & $\begin{array}{l}\text { Cross-sectional } \\
\text { quantitative study } \\
\text { with a correlational } \\
\text { and descriptive } \\
\text { approach/66 } \\
\text { participants/Cardiff } \\
\text { Wound Impact } \\
\text { Schedule. }\end{array}$ & $\begin{array}{l}\text { Discouragement with the length of time } \\
\text { for healing; fear of "hurting" the wound } \\
\text { site; concern about the wound; concern } \\
\text { about having further wounds; pain; } \\
\text { difficulty in taking bath; problems with } \\
\text { the time required to treat the wound; not } \\
\text { sleeping well; difficulty in performing } \\
\text { activities of daily living; difficulty in } \\
\text { enjoying a normal social life; not going } \\
\text { out for fear of "hurting" the wound; } \\
\text { difficulty in going out and living with } \\
\text { other people; marital status; area of } \\
\text { residence. }\end{array}$ & $\begin{array}{l}\text { Social life; physical } \\
\text { symptoms; daily life; } \\
\text { well-being; quality of } \\
\text { life in general. }\end{array}$ \\
\hline
\end{tabular}




\begin{tabular}{|c|c|c|c|c|}
\hline Reference & Objectives & $\begin{array}{l}\text { Method/ Participants/ } \\
\text { Instrument }\end{array}$ & $\begin{array}{l}\text { Factors that influence on quality of } \\
\text { life }\end{array}$ & Dimensions affected \\
\hline $\begin{array}{l}\text { Dias TYAF et al. } \\
\text { Rev Latinoam } \\
\text { Enferm. 2014; } \\
\text { 22(4): } 576- \\
81^{(18)} \text {. }\end{array}$ & $\begin{array}{l}\text { To compare the quality } \\
\text { of life of patients with } \\
\text { chronic venous diseases } \\
\text { with and without ulcers } \\
\text { and identify the most } \\
\text { affected aspects. }\end{array}$ & $\begin{array}{l}\text { Cross-sectional } \\
\text { comparative study } \\
\text { with a quantitative } \\
\text { approach/204 } \\
\text { participants/SF-36. }\end{array}$ & $\begin{array}{l}\text { Reduced mobility; poor income; low } \\
\text { education level; disturbance in the } \\
\text { sleep pattern; pain; chronic diseases. }\end{array}$ & $\begin{array}{l}\text { Functional capacity; } \\
\text { limitation due to } \\
\text { physical aspects; social } \\
\text { aspect; physical aspect. }\end{array}$ \\
\hline $\begin{array}{l}\text { Lozano SFS } \\
\text { et al. Phlebol. } \\
\text { 2014; 29(4): } \\
220-6^{(19)} \text {. }\end{array}$ & $\begin{array}{l}\text { To determine the } \\
\text { possible differences in } \\
\text { the disease and quality } \\
\text { of life (QoL) among } \\
\text { group C5 (healed ulcer), } \\
\text { group C6 (active ulcer), } \\
\text { and group C1 (control). }\end{array}$ & $\begin{array}{l}\text { Multicenter and } \\
\text { observational case- } \\
\text { control cross-sectional } \\
\text { study/449 participants/ } \\
\text { Short Form } 12 \text { Health } \\
\text { Survey (SF-12). }\end{array}$ & $\begin{array}{l}\text { Pain; varicose veins; edema; skin } \\
\text { pigmentation; inflammation; } \\
\text { induration; number of wounds, size } \\
\text { of wounds, and length of time of the } \\
\text { wounds. }\end{array}$ & $\begin{array}{l}\text { No correlation was } \\
\text { found between the } \\
\text { scores of total and } \\
\text { individual dimensions } \\
\text { evaluated with the } \\
\text { dimensions affected in } \\
\text { the instrument used. }\end{array}$ \\
\hline $\begin{array}{l}\text { Torres GV et } \\
\text { al. Rev Enferm } \\
\text { UERJ. 2014; } \\
\text { 22(1): } 57-64^{(20)} \text {. }\end{array}$ & $\begin{array}{l}\text { To compare the } \\
\text { dimensions of health- } \\
\text { related quality of life } \\
\text { (HRQoL) of patients } \\
\text { with venous ulcers } \\
\text { (VU) admitted at the } \\
\text { Onofre Lopes University } \\
\text { Hospital (HUOL, as } \\
\text { per its acronym in } \\
\text { Portuguese), in Natal, } \\
\text { capital city of the state } \\
\text { of Rio Grande do } \\
\text { Norte, Brazil, and in } \\
\text { four primary healthcare } \\
\text { units in Evora, a city in } \\
\text { Portugal. }\end{array}$ & $\begin{array}{l}\text { Comparative and } \\
\text { analytical cross- } \\
\text { sectional study, with a } \\
\text { quantitative approach } \\
\text { of data analysis/130 } \\
\text { participants/SF-36. }\end{array}$ & $\begin{array}{l}\text { Impaired mobility; limitations and } \\
\text { restrictions to perform activities } \\
\text { of daily living such as: walking, } \\
\text { taking bath, working, traveling, } \\
\text { sleeping, and cleaning; difficulty } \\
\text { in committing/remaining at work; } \\
\text { pain; social activities affected; } \\
\text { physical changes; financial costs; } \\
\text { psychological, emotional, and social } \\
\text { implications. }\end{array}$ & $\begin{array}{l}\text { Functional capacity; } \\
\text { physical aspect; general } \\
\text { health condition; } \\
\text { vitality; social aspects; } \\
\text { emotional aspect; } \\
\text { mental health; pain. }\end{array}$ \\
\hline $\begin{array}{l}\text { Wachholz PA } \\
\text { et al. An Bras } \\
\text { Dermatol. } \\
2014 ; 89(1) \text { : } \\
73-81^{(21)} \text {. }\end{array}$ & $\begin{array}{l}\text { To identify the impact of } \\
\text { leg ulcers on patients' } \\
\text { quality of life with the } \\
\text { use of the Dermatology } \\
\text { life Quality Index, } \\
\text { and define the main } \\
\text { factors correlated to this } \\
\text { perception. }\end{array}$ & $\begin{array}{l}\text { Non-probabilistic } \\
\text { cross-sectional sample } \\
\text { study/41 participants/ } \\
\text { Dermatology Life } \\
\text { Quality Index (DLQI). }\end{array}$ & $\begin{array}{l}\text { Wound etiology; pain related to the } \\
\text { ulcer; length of time of the beginning } \\
\text { of the wound and severity of the } \\
\text { depressive symptoms. }\end{array}$ & $\begin{array}{l}\text { Symptoms and feelings; } \\
\text { work and study; size of } \\
\text { the wounds; number of } \\
\text { wounds; pain. }\end{array}$ \\
\hline $\begin{array}{l}\text { Finlayson KJ et } \\
\text { al. Int Wound } \\
\text { J. 2014; } 11 \text { : } \\
21-7^{(22)} \text {. }\end{array}$ & $\begin{array}{l}\text { To compare the } \\
\text { effectiveness of a } \\
\text { four-layer compression } \\
\text { bandage system and a } \\
\text { Class } 3(30-35 \mathrm{mmHg}) \\
\text { knit compression system } \\
\text { in healing and quality of } \\
\text { life results. }\end{array}$ & $\begin{array}{l}\text { Randomized controlled } \\
\text { trial/103 participants/ } \\
\text { Quality of Life Index. }\end{array}$ & Depression; anxiety; pain. & $\begin{array}{l}\text { Activities of daily } \\
\text { living; health support; } \\
\text { psychological } \\
\text { perspectives. }\end{array}$ \\
\hline $\begin{array}{l}\text { Salomé GM et } \\
\text { al. World J Surg. } \\
2014 ; 38: 233- \\
240^{(23)} \text {. }\end{array}$ & $\begin{array}{l}\text { To evaluate the } \\
\text { relationship of quality of } \\
\text { life with the health and } \\
\text { self-esteem of patients } \\
\text { with leg venous ulcers } \\
\text { after skin grafts. }\end{array}$ & $\begin{array}{l}\text { Non-randomized } \\
\text { multicenter and } \\
\text { controlled prospective } \\
\text { clinical trial/100 } \\
\text { participant/SF-36. }\end{array}$ & $\begin{array}{l}\text { Unemployment; early retirement; low } \\
\text { education level; smoking; chronic } \\
\text { diseases; pain; chronic venous } \\
\text { ulcer wound; functional limitations; } \\
\text { frustration; social isolation; wound } \\
\text { odor; wound's aesthetic aspect; } \\
\text { sleeping disorder; lack of strength; } \\
\text { concerns; frustration; low self- } \\
\text { esteem; self-concept. }\end{array}$ & $\begin{array}{l}\text { Functional capacity; } \\
\text { limitation due to } \\
\text { physical aspect; } \\
\text { pain; general health } \\
\text { condition; vitality; } \\
\text { social aspects; } \\
\text { emotional aspect; } \\
\text { mental health. }\end{array}$ \\
\hline $\begin{array}{l}\text { Sell BT et al. } \\
\text { Wounds. J } \\
\text { Health Sci. } \\
2015 ; 17(3) \text { : } \\
160-4^{(24)}\end{array}$ & $\begin{array}{l}\text { To verify the QoL } \\
\text { index of patients with } \\
\text { vasculogenic ulcers } \\
\text { admitted in a university } \\
\text { hospital of the south } \\
\text { region of Brazil, through } \\
\text { Ferrans and Powers } \\
\text { Quality of Life Index- } \\
\text { Wound Version. }\end{array}$ & $\begin{array}{l}\text { Descriptive cross- } \\
\text { sectional study, } \\
\text { with a quantitative } \\
\text { approach/31 } \\
\text { participants/Ferrans } \\
\text { and Powers Quality } \\
\text { of Life Index-Wound } \\
\text { Version. }\end{array}$ & $\begin{array}{l}\text { Healthcare; pain; friends; financial } \\
\text { independence; satisfaction; family } \\
\text { happiness. }\end{array}$ & Health and functioning. \\
\hline
\end{tabular}




\begin{tabular}{|c|c|c|c|c|}
\hline Reference & Objectives & $\begin{array}{l}\text { Method/ Participants/ } \\
\text { Instrument }\end{array}$ & $\begin{array}{l}\text { Factors that influence on quality of } \\
\text { life }\end{array}$ & Dimensions affected \\
\hline $\begin{array}{l}\text { Tracz E et al. } \\
\text { Holist Nurs } \\
\text { Pract. 2015; } \\
\text { 29(2): 96- } \\
102^{(25)}\end{array}$ & $\begin{array}{l}\text { To analyze quality of } \\
\text { life in patients with } \\
\text { advanced chronic } \\
\text { venous insufficiency } \\
\text { in the context of most } \\
\text { used clinical scores for } \\
\text { the classification of this } \\
\text { disease. }\end{array}$ & $\begin{array}{l}\text { Critical evaluation } \\
\text { study/42 participants/ } \\
\text { Quality of Life Survey- } \\
\text { WHOQOL. }\end{array}$ & $\begin{array}{l}\text { Pain and discomfort; self-assessment; } \\
\text { mobility; activities of daily living; } \\
\text { treatments; capacity to work; } \\
\text { interpersonal relationships; social } \\
\text { support; sexual activity; physical and } \\
\text { mental safety; home environment; } \\
\text { financial potential; health and welfare } \\
\text { (accessibility and quality); capacity to } \\
\text { acquire new skills and information; free } \\
\text { time (participation and ability to relax). }\end{array}$ & $\begin{array}{l}\text { Physical, psychological; } \\
\text { level of independence; } \\
\text { social relationships; } \\
\text { environment. }\end{array}$ \\
\hline $\begin{array}{l}\text { Araújo RO, et } \\
\text { al. Aquichan. } \\
2016 ; 16(1): \\
56-66^{(26)} \text {. }\end{array}$ & $\begin{array}{l}\text { To analyze the impact of } \\
\text { venous ulcers (VU) on } \\
\text { the quality of life }(\mathrm{QoL}) \\
\text { of users of the primary } \\
\text { health care. }\end{array}$ & $\begin{array}{l}\text { Quantitative and } \\
\text { descriptive cross- } \\
\text { sectional study/101 } \\
\text { participants/Charing } \\
\text { Cross Venous Ulcer } \\
\text { Questionnaire (CCVUQ). }\end{array}$ & $\begin{array}{l}\text { Recurrences; pain; emotional } \\
\text { condition impairment; aesthetic; } \\
\text { social exclusion and loss of privacy; } \\
\text { walking difficulty. }\end{array}$ & $\begin{array}{l}\text { Household activities; } \\
\text { social interaction; } \\
\text { emotional state; } \\
\text { aesthetic. }\end{array}$ \\
\hline
\end{tabular}

With regard to the instrument used to evaluate quality of life as shown in Chart 1, a prevalence of Short Form-36 (SF-36) was found in the studies. This instrument was used in seven studies $^{(13-16,18,20,23)}$, followed by the instruments: Cardiff Wound Impact Schedule $(\mathrm{n}=01)^{(17)}$; Short Form 12 Health Survey $(\mathrm{n}=1)$ (19); Dermatology Life Quality Index $(n=1)^{(21)}$; Quality of Life Index $(n=1)^{(22)}$; Ferrans and Powers Quality of Life Index-Wound Version $(n=1)^{(24)}$; Quality of Life Survey-WHOQOL $100(n=1)$ (15); and Charing Cross Venous Ulcer Questionnaire $(n=1)^{(26)}$.

The instrument SF-36 evaluates issues such as functional capacity, limitation due to physical aspect, pain, general health condition, vitality, social aspects, emotional aspect, and mental health. The Cardiff Wound Impact Schedule evaluates well-being, physical symptoms and daily life, social life, and quality of life in general. The Short Form 12 Health Survey (SF-12) evaluates physical function, physical aspect, pain, general health, vitality, social function, emotional aspect, and mental health. The Dermatology Life Quality Index (DLQI) evaluates issues regarding symptoms and feelings, activities of daily living, leisure, work and school, personal relationships, and treatment.

The Quality of Life Index measures dimensions regarding activities, daily life, health support, and psychological perspectives. The Ferrans and Powers Quality of Life Index-Wound Version evaluates issues regarding socioeconomic, family, psychological/ spiritual, health, and functioning aspects. The instrument Quality of Life Survey-WHOQOL 100 evaluates physical and psychological issues, level of independence, social relationships, environment, and spiritual/religion/personal beliefs aspects. The instrument Charing Cross Venous Ulcer Questionnaire evaluates household activities, social interaction, emotional state, and aesthetics.

\section{DISCUSSION}

During the selection of potential bibliographies and the full reading of the articles, data categorization was carried out. This step considered the similarities among the materials selected. The following three categories emerged, which enabled the discussion of the theme: "The importance of assessing quality of life in patients with chronic venous ulcers"; "Difficulties, limitations, and feelings regarding patients with chronic venous ulcers"; and "What must be done for the improvement of quality of life in patients with chronic venous ulcers."

\section{The importance of assessing quality of life in patients with chronic venous ulcers}

Chronic venous ulcers cause several changes in patients' lives due to pain, difficulty of locomotion, exudate, odor, and other aspects. These can lead to mood swings and changes in family relationships and social conviviality ${ }^{(13)}$, thus making activities of daily living and social activities depend on how patients are feeling.

Activities of daily living such as going up or down stairs, moving around the house, standing up without support, bathing, and dressing ${ }^{(14,18)}$ tend to bring negative repercussions to patients who, in general, also suffer from balance and walking difficulties ${ }^{(9)}$. Therefore, consequences of the pathological process lead to limitations and changes that impact quality of life and psychosocial and motor aspects, thus promoting restrictions on activities of daily living ${ }^{(15)}$.

Chronic venous ulcers compromise patients' lives regarding functional capacity, limitations due to physical aspects, pain, general health condition, vitality, social aspects, emotional aspects, and mental health ${ }^{(14)}$. Therefore, assessment of the quality of life of patients with chronic venous ulcers is of utmost importance, because this is a response indicator of the wound's healing process ${ }^{(13)}$. In addition, it provides indicators of which aspects may compromise the perception that patients present due to the pathology, and which feelings emerge based on this perception of living with the wound.

\section{Difficulties, limitations, and feelings of patients with chronic venous ulcers}

Patients with chronic venous ulcers present difficulties in performing simple activities of daily living. Wounds affecting the lower limbs interfere with locomotion, causing several limitations, thus forcing patients who live with the wounds to reorganize their daily activities. In addition, they feel dependent on others ${ }^{(18)}$ due to the etiology, pain associated with the ulcer, length of time from beginning of the wound, and severity of the depressive symptoms ${ }^{(21)}$.

The difficulty in committing to/remaining at work, in addition to difficulties in performing daily and social activities, 
lead to repercussions due to physical restrictions, pain, and the psychological, emotional, and social implications caused by the wound ${ }^{(20)}$. Consequently, limitations resulting from the wounds become big obstacles for the performance of activities of daily living, as well as for clinical follow-up, because patients present difficulties in traveling to healthcare services ${ }^{(27)}$.

Another fact that is worth mentioning is the high amount of resources needed for the treatment ${ }^{(19)}$. Although public healthcare networks offer treatment, patients tend to allocate substantial resources to pay for medication/coverage, and when they are absent from work or are early retired because of the wound, they start reflecting on expenses and tend to abandon treatment to cover their own and their families' subsistence.

Chronic venous ulcers, in addition to physical changes and financial charges, bring implications of psychological and social context, extended to family and social spheres, thus showing the complexity of this problem ${ }^{(16)}$. Consequently, chronic venous ulcers bring feelings of anxiety and depression disorders to patients, which tend to cause delays in the healing process of wounds from acute conditions $^{(22)}$. Therefore, promoting psychological well-being to patients is necessary for the improvement of their clinical condition.

Unemployment/early retirement that affect patients who experience the wound, pain, functional limitations, feeling of frustration, odor, and aesthetic aspect that discourage interaction. This can lead to social isolation, lack of strength, concerns, low self-esteem, self-concept ${ }^{(23)}$, and physical and social safety ${ }^{(25)}$. These are issues that also reflect the feelings of patients with venous ulcers, thus impacting quality of life, which suggests that care must address all life aspects of these patients.

\section{What must be done for the improvement of quality of life} in patients with chronic venous ulcers

For improvement of the quality of life of patients with venous ulcers, therapies must be optimized, doubts that may emerge must be clarified, and activities that relieve tensions and promote wellbeing and autonomy to patients and their families must be provided, through the adoption of best practice that ensures coherence and solidity to the care provided during the treatment process ${ }^{(17)}$.

The nursing area has an important role in the care provided to these patients regarding therapeutic procedures that involve assessment of the diagnosis and healing process, as well as in the prevention of harm related to the pathology. This prevention must occur by means of the development/application of new technical interventions in nursing care and healthcare with the aim of recovery and rehabilitation of both patients and families involved in the care process.

Therefore, nurses who provide care to this population must be attentive to the evolution of the disease and seek the prevention of other wounds, recurrences, and the appropriate treatment for the healing of the wound, with the aim of reducing damage that the clinical condition promotes in the quality of life of these patients ${ }^{(18)}$. For this purpose, care must be focused not only on the wounds, but also on the patients who live with them, by intervening in the factors that compromise quality of life ${ }^{(20)}$.

During care, healthcare professionals usually do not ask about patients' concerns and complaints. They do not discuss them and there are no changes in the care process in order to resolve and minimize patients' concerns.
Nursing professionals must provide patients with comprehensive care, because patients with chronic venous ulcers are impaired in both bio-psycho-spiritual and socioeconomic aspects. Thus, professionals must be attentive to notice patients' weaknesses and intervene appropriately, not only focusing on clinical diagnoses, but also encouraging patients to face the difficulties resulting from their clinical condition, and providing them with comfort and well-being for possible improvement in their quality of life ${ }^{(13)}$.

One study selected during the search ${ }^{(24)}$ showed that, to improve the quality of life of these patients, updates of guidelines and protocols for the care of this type of wound are of the utmost importance, in addition to investments to improve quality of care by training multidisciplinary teams and providing health education for professionals and family members/caregivers.

Based on the abovementioned study, the importance of clinical conduct in the treatment of chronic venous insufficiency stands out, because signs and symptoms of the disease are directly associated with the impairment of quality of life in the population affected. Therefore, it is of utmost importance that the care provided to patients with chronic venous ulcers presents a drug therapy approach, topical therapy with local coverage, promotion of exudate control through the use or not of compression therapies, control of secondary infections, and prevention of recurrences ${ }^{(4)}$ by means of post-healing follow-up by an angiologist. In addition, identification of specificities demanded by each patient are important, because patients who present wounds for a longer time tend to present a greater impairment of quality of life compared to those who live with the wounds for less than one year ${ }^{26)}$.

The adoption of educational support for patients is also necessary, because low education level was shown in the present study as one of the factors that influences quality of life. This influence may be related to the lack of understanding of health recommendations, which tends to compromise the clinical conducts adopted and consequently lead to post-healing process recurrences. Therefore, the use of strategies based on education and health regarding patients' education level is of utmost importance, so that they are able to understand the clinical conduct adopted and actively participate as protagonists in their recovery process.

\section{Study limitations}

The current study presented as a limitation the fact that the research was based on articles from 2007 to 2016, and the articles selected with the criteria adopted were from 2012 to 2016. This may be related to the databases adopted for the development of the study.

Contributions to the nursing, healthcare, or public policy areas

The main contribution of the present study to the scientific research field in venous ulcers and the nursing area was to identify the factors that affect the quality of life of patients with chronic venous ulcers and the dimensions affected, namely those related to functional capacity, physical aspect, pain, general health condition, vitality, social aspects, emotional aspects, and mental health. These findings become especially relevant because impairment of quality of life will impact what patients feel about themselves and about presenting wounds, considering that these wounds significantly affect the performance of daily work and leisure activities. 
These reflections enable professional improvement and the adoption of new healthcare interventions aimed at the recovery and rehabilitation of patients and their families.

\section{CONCLUSION}

The present study enabled an analysis of the impact of chronic venous ulcers on patients' quality of life, because the results identified that these wounds negatively impact on patients' integrality (bio-psycho-spiritual) and their socioeconomic sphere.

Therefore, patients with chronic venous ulcers must receive care based on kindness and sensible listening, in addition to emotional and psychological support during their treatment.
The development of the following assessment studies are recommended: strategies for the reduction in damages regarding venous ulcers on patients' quality of life; evaluation of the repercussions of psychological follow-up of patients on the healing process; and comparison of the assessment instruments regarding quality of life, with the aim to identify the best tool to measure the impacts of chronic venous ulcers' wounds.

\section{ACKNOLEDGEMENT}

To Colegio Doctoral Tordesillas de Enfermería for enabling the development of the present study through the partnership between the Fluminense Federal University (Brazil) and the Granada University (Spain), as well as the universities involved.

\section{REFERENCES}

1. Nunes HJM, Queirós PJP. Patient with stroke: hospital discharge planning, functionality and quality of life. Rev Bras Enferm [Internet]. 2017 [cited 2017 May 17];70(2):433-42. Available from: http://www.scielo.br/pdf/reben/v70n2/0034-7167-reben-70-02-0415.pdf

2. Scottish Intercollegiate Guidelines Network. Management of chronic venous leg ulcers: a national clinical guideline. Edinburgh: Scottish Intercollegiate Guidelines Network [Internet] 2010 [cited 2017 May 17];1-46. Available from: http://www.sign.ac.uk/ assets/sign120.pdf

3. Belczack SQ, Gornati VC, Aun R, Sincos IR, Fragoso H. Treatment of varicose ulcer of the lower limbs by surgery and Unna boot: savings for the Brazilian healthcare system. Einstein [Internet]. 2011[cited 2017 May 17];9(3):377-85. Available from: http://www. scielo.br/pdf/eins/v9n3/1679-4508-eins-9-3-0377.pdf

4. Barbosa JAG, Campos LMN. Guidelines for the treatment of venous ulcer. Enferm Glob [Internet]. 2010[cited 2017 May 18];20:113. Available from: http://scielo.isciii.es/pdf/eg/n20/pt_revision2.pdf

5. Asociación Española de Enfermería Vascular y Heridas. Guía de práctica clínica: Consenso sobre úlceras vasculares y pie diabético. Sevilla: AEEVH [Internet]. 2014[cited 2017 May 18];2:1-90. Available from: https://www.aeev.net/pdf/AEEV\%2035\%20.pdf

6. Evangelista DG, Magalhães ERM, Moretão DIC, Stival MM, Lima LR. Impact of chronic wounds in the quality of life for users of family health strategy. Rev Enferm Centro O Min [Internet]. 2012 [cited 2018 Jul 18];2(2):254-63. Available from: http://www.seer. ufsj.edu.br/index.php/recom/article/download/15/308

7. Silva FAA, Moreira TMM. Sociodemografic and clinical characteristics of customers with venous leg ulcer. Rev Enferm UERJ [Internet]. 2011 [cited 2017 May 18];19(3):468-72. Available from: http://www.facenf.uerj.br/v19n3/v19n3a22.pdf

8. OMS. Promoción de la Salud. Glossario. Genebra: OMS; 1998.

9. Joaquim FL, Camacho ACLF, Sabóia VM, Santos RC, Santos LSF, Nogueira GA. Impact of home visits on the functional capacity of patients with venous ulcers. Rev Bras Enferm [Internet]. 2016 [cited 2017 May 18];69(3):439-47. Available from: http://www. scielo.br/pdf/reben/v69n3/en 0034-7167-reben-69-03-0468.pdf

10. Mendes KDS, Silveira RCCP, Galvão CM. Integrative literature review: a research method to incorporate evidence in health care and nursing. Texto Contexto Enferm [Internet]. 2008 [cited 2017 May 18];17(4):758-764. Available from: http://www.scielo.br/ pdf/tce/v17n4/18.pdf

11. Stillwell SB, Fineout-Overhoult E, Melnyk BM, Williamson KM. Searching for the evidence: strategies to help you conduct a successful search. Am J Nurs[Internet]. 2010 [cited 2017 May 18];110(5):41-7. Available from: http://www.nursingcenter.com/ nursingcenter_redesign/media/EBP/AJNseries/Searching.pdf

12. Galvão TF, Pansani TSA, Harrad D. Main items to report Systematic reviews and meta-analyzes: the recommendation PRISMA. Epidemiol Serv Saúde [Internet]. 2015[cited 2017 Jun 07];24(2):335-42. Available from: http://www.scielo.br/pdf/ress/v24n2/22379622-ress-24-02-00335.pdf

13. Salomé GM, Ferreira LM. Quality of life in patients with venous ulcers treated with Unna's boot compressive therapy. Rev Bras Cir Plást [Internet]. 2012 [cited 2017 Jun 05];27(3):466-71. Available from: http://www.scielo.br/pdf/rbcp/v27n3/en_24.pdf

14. Dias TYAF, Costa IKF, Liberato SMD, Souza AJG, Mendes FRP, Torres GV. Quality of life for venous ulcer patients: a comparative study in Brazil/Portugal. O Braz J Nurs [Internet]. 2013[cited 2017 Jun 05];12(2):491-500. Available from: http://www.objnursing. uff.br/index.php/nursing/article/view/4344/pdf

15. Lopes CR, Figueiredo M, Ávila AM, Soares LMBM, Dionisio VC. Evaluation of limitations of venous ulcers in legs. J Vasc Bras [Internet]. 2013 [cited 2017 Jun 05];12(1):5-9. Available from: http://www.scielo.br/pdf/jvb/v12n1/en_03.pdf 
16. Dias TYAF, Costa IKF, Salvetti MG, Mendes CKTT, Torres GV. Influences of health care services and clinical characteristics on the quality of life of patients with venous ulcer. Acta Paul Enferm [Internet]. 2013 [cited 2017 Jun 05];26(6):529-34. Available from: http://www.scielo.br/pdf/ape/v26n6/en_04.pdf

17. Saraiva DMRF, Bandarra AJF, Agostinho ES, Pereira NMM, Lopes TS. Quality of life of service users with chronic venous ulcers. Referência [Internet]. 2013 [cited 2017 Jun 05];3(10):109-18. Available from: http://www.scielo.mec.pt/pdf/ref/vserlllnn10/serllln10a13.pdf

18. Dias TYAF, Costa IKF, Melo MDM, Torres SMSGSO, Maia EMC, Torres GV. Quality of life assessment of patients with and without venous ulcer. Rev Latino-Am Enfermagem[Internet]. 2014 [cited 2017 Jun 05];22(4):576-81. Available from: http://www.scielo.br/ pdf/rlae/v22n4/0104-1169-rlae-22-04-00576.pdf

19. Lozano SFS, Marinel JR, Carrasco EC, González RJP, Escudero RJR, Sánchez IN, et al. Venous leg ulcer in the context of chronic venous disease. Phlebol [Internet]. 2014 [cited 2017 Jun 05];29(4):220-6. Available from: http://journals.sagepub.com/doi/ pdf/10.1177/0268355513480489

20. Torres GV, Balduino LSC, Costa IKF, Mendes FRP, Vasconcelos QLDAQ. Comparison of quality of life domains in patientswith venous ulcer. Rev Enferm UERJ [Internet]. 2014 [cited 2017 Jun 05];22(1):57-64. Available from: http://www.facenf.uerj.br/v22n1/ v22n1a09.pdf

21. Wachholz PA, Masuda PY, Nascimento DC, Taira CMH, Cleto NG. Quality of life profile and correlated factors in chronic leg ulcer patients in the mid-west of São Paulo State, Brazil. An Bras Dermatol [Internet]. 2014 [cited 2017 Jun 05];89(1):73-81. Available from: http://www.scielo.br/pdf/abd/v89n1/0365-0596-abd-89-01-0073.pdf

22. Finlayson KJ, Courtney MD, Gibb MA, O'Brien JA, Parker CN, Edwards HE. The effectiveness of a four-layer compression bandage system in comparison with class 3 compression hosiery on healing and quality of life in patients with venous leg ulcers: a randomized controlled trial. Int Wound J[Internet]. 2014 [cited 2017 Jun 05];11:21-7. Available from: http://onlinelibrary.wiley. com/doi/10.1111/j.1742-481X.2012.01033.x/epdf

23. Salomé GM, Blanes L, Ferreira LM. The impact of skin grafting on the quality of life and self-esteem of patients with venous leg ulcers. World J Surg [Internet]. 2014 [cited 2017 Jun 05];38:233-40. Available from: https://link.springer.com/article/10.1007/ s00268-013-2228-x

24. Sell BT, Souza MV, Martins T, Amante LN. Quality of life of pacients with vasculogenic ulcers according to Ferrans and Powers: wounds. J Health Sci [Internet]. 2015 [cited 2017 Jun 06];17(3):160-4. Available from: http://www.pgsskroton.com.br/seer/index. php/JHealthSci/article/view/3062/2849

25. Tracz E, Zamojska E, Modrzejewski A, Zaborski D, Grzesiak W. Quality of life in patients with venous stasis ulcers and others with advanced venous insufficiency. Holist Nurs Pract [Internet]. 2015 [cited 2017 Jun 06];29(2):96-102. Available from: https:// insights.ovid.com/pubmed?pmid $=25658932$

26. Araújo RO, Silva DC, Souto RQ, Marconato AMP, Costa IKF, Torres GV. Impact of varicose ulcers on the quality of life of persons receiving primary care. Aquichan [Internet]. 2016 [cited 2017 Jun 06];16(1):56-66. Available from: http://www.scielo.org.co/pdf/ aqui/v16n1/v16n1a07.pdf

27. Green J, Jester R, Mckinley A, Pooler S, Mason S, Redsell S. A new quality of life consultation template for patients with venous leg ulceration. J Wound Care [Internet]. 2015 [cited 2017 Jun 06];24(3):140-8. Available from: http://www.magonlinelibrary.com/ doi/pdf/10.12968/jowc.2015.24.3.140 